\title{
Biosorption Potentials of Pleurotus tuber-regium (Fr.) Sing in Lead and Cadmium Polluted Soil
}

\author{
Adumanya, O.C.U. ${ }^{1,{ }^{*}}$, Onwubuche, B.C. ${ }^{2}$, Nwinee, S.A. ${ }^{3}$ and Umensofor G.A. ${ }^{4}$ \\ ${ }^{1}$ Biochemistry Department, University of Agriculture \& Environmental Sciences, Umuagwo, Imo State, Nigeria. \\ ${ }^{2}$ Department of Science Laboratory Tech. Imo State Polytechnic, Umuagwo, Imo State. \\ ${ }^{3}$ Department of Science Laboratory Tech. Petroleum Training Institute, Effurun, Delta State, Nigeria. \\ ${ }^{4}$ Department of Agric. Imo State Local Government Civil Service Commission., Nigeria.
}

*Correspondence: oadumanya@gmail.com; mobileno: +234(0)8037730442

\begin{abstract}
Background/Aim: The heavy metals, cadmium $(\mathrm{Cd})$ and lead $(\mathrm{Pb})$, are often implicated as environmental pollutants. Therefore, the biosorption potential of Pleurotus tuber-regium in lead and cadmium polluted soil was investigated by this work. Methods: Four kilograms of each humus soil sample was weighed into eight different black nursery cellophane bags and polluted with $0.5 \mathrm{~g}, 1.0 \mathrm{~g}$ and $2.0 \mathrm{~g}$ of lead and cadmium in triplicate. Pleurotus sclerotia were then planted in these polluted soil samples, and distilled water was added ad libitum. Results: The results showed that the growth performance was dose-related in lead-polluted soil. The Pleurotus tuber regium mushroom in the lead-polluted soil samples indicated a dose-dependent absorbed lead concentration in the results. Cadmium-polluted soil samples did not support the growth of the Pleurotus tuber regium mushroom at the various concentrations of cadmium used after day 30 . Therefore, the findings suggest that the Pleurotus tuber regium mushroom and its sclerotia have intrinsic properties for the absorption of lead and cadmium. Conclusion: The findings suggest that the Pleurotus tuber regium mushroom and its sclerotia have intrinsic properties for the absorption of lead and cadmium.
\end{abstract}

Keywords: Biosorption, sclerotia, soil, lead, cadmium.

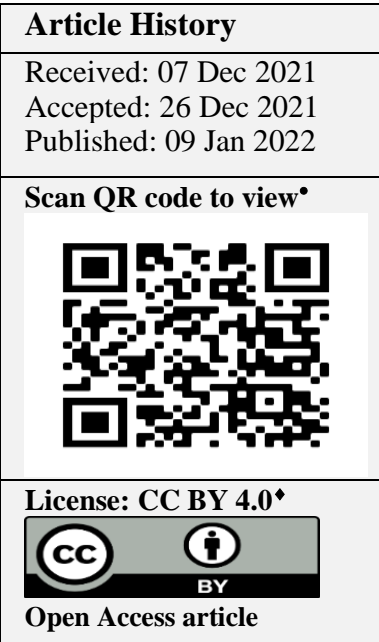

How to cite this paper: Adumanya, O.C.U., Onwubuche, B.C., Nwinee, S.A. and Umensofor G.A. (2022). Biosorption Potentials of Pleurotus tuber-regium (Fr.) Sing in Lead and Cadmium Polluted Soil. Journal of Pollution Monitoring, Evaluation Studies and Control, 1(1), 1-3. https://doi.org/10.54117/jpmesc.v1i1.1

\section{Introduction}

Heavy metals are biomagnified in the food chain because they are nonbiodegradable (Singh et al., 2008; Gupta and Singh, 2019). Because these metals produce significant contamination of the environment and obstruct various cellular functions, they constitute a risk to human health when they are carried down the food chain. They can also induce harmful effects in organisms even in trace amounts. Their effects are usually concentration dependent and vary depending on individual toxicity. As a result, removing them before final effluent release in environmental segments becomes critical.

Mushrooms and other fungi have enzymatic machinery for waste/pollutant degradation; therefore, they can be used to treat a wide range of contaminants. Mushrooms, a basidiomycetous fungus, are becoming more popular for remediation because they are not only a bioremediation tool but also a source of protein in the form of mycelium or fruiting bodies. Mushroom species' ability to breakdown waste via secretion of a variety of hydrolyzing and oxidizing enzymes allows them to produce dietary protein in the form of biomass or fruiting bodies from various wastes (Kuforiji and Fasidi, 2008). This has piqued the interest of scientists working on mushroom cultivation and waste remediation. Fruiting bodies of macrofungi (mushrooms) are considered ideal for the purpose of evaluation as biosorbents because it has been demonstrated that many fungal species exhibit high biosorptive potential (Suseem et al, 2011).
Studies have shown that mushrooms can be used to reduce the level of environmental pollution by biosorption of cadmium, copper, nickel and chromium (Gabriel et al, 2006).

Pleurotus tuber-regium (Fr.) Sing is a tuberous wild white rot basidiomycete that forms fruitbodies from a globose sclerotium that resembles a large truffle (Nwokolo, 2007). It grows on a variety of hard and soft timbers and has a tropical and subtropical range. Pleurotus tuberregium is the only Pleurotus species known to produce real sclerotium, and it differs from all other Pleurotus species in that it does not have a pleurotoid habit (Isikhuemhen and Nerud, 1999, Isikhuemhen et al., 2003). Sclerotia come in a variety of sizes, ranging from a few centimeters in diameter to several centimeters. They are spherical to oval in shape, with a dark brown exterior and a pale inside (Okhuoya and Okogbo, 2001).

Biosorption is being investigated as an option for industrial wastewater cleanup and the recovery of metals present in effluent. Biosorption is a process that occurs when a substance is absorbed into the body. Biosorption is a method of removing metal ions, contaminants, and xenobiotics from wastewater using living or dried biomass that has a high tolerance for metals and other harsh circumstances (Gavrilescu, 2004). Mushroom mycelium and discarded mushroom compost can be used to make biosorbents. Biosorption has a number of advantages over traditional treatment procedures, including low cost, high effectiveness, reduced 
chemical and biological sludge, no additional nutritional requirements, biosorbent renewal, and the possibility of metal recovery. Two pathways are involved in the uptake of pollutants/xenobiotics by mushrooms:

(i) Bioaccumulation, which comprises both transport into the cell and partitioning into intracellular components and is dependent on active metabolism; and

(ii) Biosorption, i.e., the binding of pollutants to the biomass without requiring metabolic energy.

Adsorption, ion exchange, and covalent binding are among the chemical reactions that may be implicated in biosorption. The polar groups of proteins, amino acids, lipids, and structural polysaccharides (chitin, chitosan, and glucans), according to Mar'in et al. (2007), may be implicated in the biosorption process.

$\mathrm{pH}$, temperature, nutrient supply, initial metal ion concentration, and cell concentration are some of the operational conditions for biosorption. The uptake of xenobiotics by live cells is influenced by the fungal species and the length of contact. For the elimination of contaminants, biosorption techniques are becoming increasingly common. Biosorption is a successful approach because of its high absorption capacity and low-cost raw materia source. Having considered the relevance of Pleurotus tuber-regium, the researcher therefore embarks on this study to determine the biosorption potentials of the fungus Pleurotus tuber-regium using heavy metals such as cadmium and lead.

\section{Materials and Methods}

Standard apparatus and reagents of analytical grades were used

\section{Pleurotus Sclerotium acquisition and Authentication}

Pleurotus sclerotium was procured from the Eke-Ukwu Owerri market, Imo State, and identified by a mycologist, Obi-Adumanya, A. G., of the forestry Unit of the Agriculture Department of Imo State Local Government Civil Service Commission, Owerri, Imo State, Nigeria.

\section{Soil Sample Used and Preparation}

The humus soil samples used were collected from Imo State Polytechnic, Umuagwo, Imo State, Nigeria

The soil samples collected were sterilized by autoclaving and allowed to cool. Then, they were weighed and transferred to cellophane bags. Four (4) kilograms of the soil sample was weighed into a black cellophane bag. Each of the heavy metals was weighed as follows: $0.5 \mathrm{~g}, 1.0 \mathrm{~g}, 2.0 \mathrm{~g}$ of lead; $0.5 \mathrm{~g}, 1.0 \mathrm{~g}, 2.0 \mathrm{~g}$ of cadmium. Three replicates were prepared for each of the soil samples and thoroughly mixed with the heavy metal used to contaminate the soil except for the soil in the control, which had no heavy metals.

\section{The Sclerotia Preparation and Planting}

The healthy sclerotia were soaked in clean water overnight prior to planting. It was cut to a size of $2 \mathrm{~cm}$ by $4 \mathrm{~cm}$ and planted $1 \mathrm{~cm}$ deep in the prepared bagged soil in triplicate.

\section{Sample Digestions, Cadmium and Lead levels Determination}

The content of $\mathrm{Cd}$ and $\mathrm{Pb}$ in the samples was assayed Flame atomic absorption spectrophotometer as described by Whiteside \& Miner (1984) and Gałgowska \& Pietrzak-Fie'cko (2021).

\section{Statistical analysis: One way ANOVA}

\section{Results}

The results presented in Table 1 depicts that the size of the stipe and pilus of the samples varied significantly at $\mathrm{P}<0.05$. As the lead concentrations increased it reduced the size of these measured parameters. But an increased was noticed at $2.0 \mathrm{~g}$ of lead polluted soil. Table 2 showed the biosorption of lead by grown mushroom which increased as the lead levels increased.
Tables 3 and 4 indicated that the cadmium polluted soil did not support the mushroom growth and biosorption, even at day 30 .

Table 1: Growth performance of the mushroom in lead polluted soil

\begin{tabular}{lllll}
\hline \multirow{2}{*}{ Sample } & Day 0 & \multicolumn{3}{c}{ Day 30 } \\
\cline { 2 - 5 } & $\begin{array}{l}\text { Stipe } \\
\text { Length } \\
(\mathrm{cm})\end{array}$ & $\begin{array}{l}\text { Pilus } \\
\text { Diameter }(\mathrm{cm})\end{array}$ & $\begin{array}{l}\text { Stipe } \\
\text { Length }(\mathrm{cm})\end{array}$ & $\begin{array}{l}\text { Pilus } \\
\text { Diameter(cm) }\end{array}$ \\
\hline A & 0 & 0 & $6.50 \pm 0.50^{\mathrm{a}}$ & $4.5 \pm 0.50^{*}$ \\
$\mathrm{~B}$ & 0 & 0 & $5.67 \pm 1.15^{\mathrm{a}}$ & $3.37 \pm 0.55^{* *}$ \\
$\mathrm{C}$ & 0 & 0 & $6.12 \pm 0.10^{\mathrm{a}}$ & $3.03 \pm 1.70^{* *}$ \\
$\mathrm{D}$ & 0 & 0 & $6.93 \pm 0.40^{\mathrm{b}}$ & $3.33 \pm 1.61^{* *}$ \\
\hline
\end{tabular}

Values are means standard \pm deviation, $n=3$, values with different letters differ significantly at $\mathrm{P}<0.05$

Values with $* *$ are significantly different at $\mathrm{P}<0.05$

Sample A: Pleurotus mushroom in non-lead $(\mathrm{Pb})$-polluted soil.

Sample B: Pleurotus mushroom in $0.5 \mathrm{~g} \mathrm{~Pb}$ pollution soil.

Sample C: Pleurotus mushroom in $1.0 \mathrm{~g} \mathrm{~Pb}$ pollution soil.

Sample D: Pleurotus mushroom in $2.0 \mathrm{~g} \mathrm{~Pb}$ pollution soil

Table 2: Biosorption potential of Pleurotus tuber-regium in lead $(\mathrm{Pb})$ polluted soil (Day 30).

\begin{tabular}{ll}
\hline Samples & $\mathbf{P b}(\mathbf{m g} / \mathbf{k g})$ \\
\hline Soil used & 0.061 \\
Raw Pleurotus tuber-regium & 0.000 \\
Sample A & $0.002^{\mathrm{a}}$ \\
Sample B & $0.003 \pm 0.052^{\mathrm{a}}$ \\
Sample C & $0.091 \pm 0.302^{\mathrm{b}}$ \\
Sample D & $2.469 \pm 1.57^{\mathrm{b}}$ \\
\hline
\end{tabular}

Values are means standard \pm deviation, $n=3$, values with different letters differ significantly at $\mathrm{P}<0.05$

Sample A: Pleurotus tuber-regium grown in non-lead $(\mathrm{Pb})$-polluted soil.

Sample B: Pleurotus tuber-regium grown in $0.5 \mathrm{~g} \mathrm{~Pb}$-polluted soil.

Sample C: Pleurotus tuber-regium grown in $1.0 \mathrm{~g} \mathrm{~Pb}$-polluted soil.

Sample D: Pleurotus tuber-regium grown in $2.0 \mathrm{~g}$ Pb-polluted soil.

Table 3: Growth performance of the mushroom in cadmium-polluted soil

\begin{tabular}{lllll}
\hline \multirow{2}{*}{ Sample } & Day 0 & \multicolumn{3}{c}{ Day 30 } \\
\cline { 2 - 5 } & $\begin{array}{l}\text { Stipe } \\
\text { Length } \\
(\mathrm{cm})\end{array}$ & $\begin{array}{l}\text { Pilus } \\
\text { Diameter } \\
(\mathrm{cm})\end{array}$ & $\begin{array}{l}\text { Stipe Length } \\
(\mathrm{cm})\end{array}$ & $\begin{array}{l}\text { Pilus } \\
\text { Diameter } \\
(\mathrm{cm})\end{array}$ \\
\hline $\mathrm{W}$ & 0 & 0 & $6.5 \pm 0.50$ & $4.5 \pm 0.50$ \\
$\mathrm{X}$ & 0 & 0 & No growth** & No growth** \\
$\mathrm{Y}$ & 0 & 0 & No growth** & No growth** \\
$\mathrm{Z}$ & 0 & 0 & No growth** & No growth** \\
\hline Values are means standard deviation, $\mathrm{n}=3$. ** indicates no growth \\
Sample W: Pleurotus tuber-regium grown in non-cadmium $(\mathrm{Cd})$-polluted soil. \\
Sample X: Pleurotus tuber-regium grown in 0.5 g cadmium $(\mathrm{Cd})$-polluted soil \\
Sample Y: Pleurotus tuber-regium grown in 1.0 g of cadmium $(\mathrm{Cd})$-polluted soil. \\
Sample Z: Pleurotus tuber-regium grown in 2.0 g cadmium $(\mathrm{Cd})$-polluted soil.
\end{tabular}

Table 4: Biosorption potential of Pleurotus tuber-regium in cadmiumpolluted soil

\begin{tabular}{ll}
\hline Samples & Cadmium $(\mathbf{C d}) \mathbf{~ m g / k g}$ \\
\hline Soil used & 0.000 \\
Raw Pleurotus tuber-regium & 0.003 \\
Sample W & 0.035 \\
Sample X & 0.000 \\
Sample Y & 0.000 \\
Sample Z & 0.000 \\
\hline Sample W: Pleurotus tuber-regium grown in non-cadmium $(\mathrm{Cd})$-polluted soil. \\
Sample X: Pleurotus tuber-regium grown in $0.5 \mathrm{~g} \mathrm{Cd-polluted} \mathrm{soil.}$ \\
Sample Y: Pleurotus tuber-regium grown in $1.0 \mathrm{~g} \mathrm{Cd-polluted} \mathrm{soil.}$ \\
Sample Z: Pleurotus tuber-regium grown in $2.0 \mathrm{~g}$ Cd-polluted soil.
\end{tabular}

\section{Discussion}

Most heavy metals have toxic effects on living organisms at certain concentrations. Some metals are subject to bioaccumulation and may pose a risk to human health when transferred through the food chain (Jamp, 2003).

In this study, the potential of Pleurotus tuber-regium to absorb heavy metals used to contaminate the soil was assayed. Fruit body emergence 
occurred quicker in lead-contaminated soil, which could indicate the mushroom's tolerance to ongoing lead poisoning. A similar effect of lead tolerance by Pleurotus tuber-regium was observed by Akpaja et al. (2012) at $0.5 \mathrm{mmol}$ lead contamination. They concluded that lead-contaminated soils reduced soil fertility and directly affected changes in physiological indices, which caused a decline in mushroom fields.

The fresh heights of the mushrooms harvested from lead-contaminated soil were lower than those of the control. This is also an indication that Pleurotus tuber-regium could have absorbed lead from the soil.

The reduction in height could be associated with lead absorption and accumulation in the mushroom. This result agrees with the findings of Kalac and Svoboba (2000) and Ita et al. (2006), who reported that an increase in the mass of the fruit body of wild and edible mushrooms was associated with the concentration of metals. Akpaja et al. (2012) reported that lead greatly affected Pleurotus tuber-regium morphometry. This contradiction could be associated with the concentration and type of lead used.

For biological species to be used in bioremediation, they must have a bioaccumulation tendency. The bioaccumulation factor showed that Pleurotus tuber-regium may be useful in the bioremediation of continuously contaminated soil with respective metals.

Cadmium prevented growth and fruit body production in Pleurotus tuberregium, i.e. acted as an inhibitor of the growth of Pleurotus tuber-regium. Cadmium has been found to be present in higher concentrations in caps (22-56 mg/kg dry wt) than in stipes (13-36 mg/kg dry wt) (Favero et al.

\section{References}

Akpaja E. O., Nwogu, N. A. and Odibo, E. A. (2012). Effect of Heavy Metals on the Growth and Development of Pleurotus tuber-regium. Mycosphere. 3(1): 57 - 60. https://doi.org/10.5943/mycosphere/3/1/6

Favero, N., Bressa, G. and Costa, P. (2000) Response of Pleurotus ostreatus to cadmium exposure. Ecotoxicol Environ Safe 20(1):1-6 https://doi.org/10.1016/0147-6513(90)90039-8

Gabriel, J., Capelari, M., and Zadrazil, F. (2006). Influence of cadmium on the growth of Agrocybe perfecta and two Pleurotus spp and translocation from polluted substrate and soil to fruit bodies. Toxicological and Environmental Chemistry. 56: 141-146. https://doi.org/10.1080/02772249609358356

Gałgowska, M and Pietrzak-Fie'cko, R. (2021). Cadmium and Lead Content in Selected Fungi from Poland and Their Edible Safety $\begin{array}{lll}\text { Assessment. } \quad \text { Molecules, } & & \\ \end{array}$ https://doi.org/10.3390/molecules26237289

Gavrilescu, M. (2004). Removal of heavy metals from the environment by biosorption. Eng Life Sci. $4: 219-232$. https://doi.org/10.1002/elsc.200420026

Gupta, E. and Singh, P. (2019). Chapter 6: Microbial Polysaccharides as the Renewable Substrate for Bioabsorption: A Cost Effective Technology,Pg 124

Isikhuemhen, O.S. and Nerud, F. (1999). Preliminary Studies on the Ligninolytic Enzymes Produced by the Tropical Fungus Pleurotus tuber-regium (Fr.) Sing. Antonie van Leeuwenhoek, 75, 257-260. https://doi.org/10.1023/A:1001871101604

Isikhuemhen, O.S., Anoliefo, G. and Oghale, O. (2003). Bioremediation of crude oil polluted soil by the white rot fungus Pleurotus tuber-regium (Fr.) Sing. sclerotia. Environmental Science Pollution 10:108-112. https://doi.org/10.1065/espr2002.04.114

Ita B. N., Essien J. P., Ebong G. A. (2006). Heavy metal levels in fruiting bodies of edible and nonedible mushrooms from the Niger delta region of Nigeria. J Agric Soc Sci 2:84-87.

\footnotetext{
- Thanks for publishing with IPS Intelligentsia.
}

2000 ) in $P$. ostreatus. When exposed to a concentration of up to $285 \mathrm{mg}$ $\mathrm{Cd} / \mathrm{kg}$ of dried substrate, fruit body formation was shown to be unaffected. Pleurotus species have been discovered to be resistant to high $\mathrm{Cd}$ levels (Gabriel et al. 2006). Their ability to absorb heavy metals can render them immobile, yet consumption by other creatures can result in heavy metal translocation farther up the food chain (Osman and Bandyopadhyay, 2009). The results showed that the growth performance was dose-related in lead-polluted soil. The Pleurotus tuber regium mushroom in the leadpolluted soil samples indicated a dose-dependent absorbed lead concentration, as shown in the results. Cadmium-polluted soil samples did not support the growth of the Pleurotus tuber regium mushroom at the type and various concentrations of cadmium used after day 30 .

\section{Conclusion}

The Pleurotus tuber regium mushroom in the lead-polluted soil samples indicated a dose-dependent absorbed lead concentration, as shown in the results. Cadmium-polluted soil samples did not support the growth of the Pleurotus tuber regium mushroom at the various concentrations of cadmium used after 30 days. Therefore, the findings suggest that Pleurotus tuber regium has intrinsic properties for the absorption of lead and cadmium.

\section{Conflict of Interest}

Authors declare no conflict of interest.

\section{Acknowledgment}

Tetfund Nigeria via Imo State Polytechnic is acknowledged for sponsoring this work.

Jamp, L. (2003). Hazzards of Heavy Metal Contamination. Medical Bulletin. 68: 167 - 182. https://doi.org/10.1093/bmb/ldg032

Kalac, P. and Svoboda, L. (2000). A review of trace element concentrations in edible mushrooms. Food Chem. 69:273-281. https://doi.org/10.1016/S0308-8146(99)00264-2

Mar'in A, Conti C, and Gobbi, G. (2007). Sorption of lead and cesium by mushrooms grown in natural conditions. Res Environ Biotechnol. 4:35-49.

Nwokolo, E. (2007). Composition of nutrients in the sclerotium of the mushroom Pleurotus tuber-regium. Plant Foods and Human Nutrition 37: 133-139. https://doi.org/10.1007/BF01092049

Okhuoya, J. A. and Okogbo, F. O. (2001). Cultivation of Pleurotus tuberregium (Fr.) Sing. on various farm wastes. Proceedings of Oklahoma Academy of Science 71:1-3.

Osman M. S. and Bandyopadhyay M. (1999). Bioseparation of lead ions from wastewater by using a fungus P. ostreatus. J Civil Eng 27:183196.

Oso, B. A. (2007). Pleurotus tuber-regium from Nigeria mycologia, 69: 271-9. https://doi.org/10.1080/00275514.1977.12020058

Singh, J., Kant, K., Sharma, H. B., and Rana, K. S. (2008). Bioaccumulation of cadmium in tissues of Cirrihna mrigala and Catla catla. Asian J Exp Sci 22:411-414.

Suseem S. R., Mary S. A, Neelakanta P. R. and Marslin G. (2011). Food chemistry. Asian Pacific Journal of Tropical Medicine., 2011; 412420 .

Kuforiji O. O, Fasidi I. O. (2008). Enzyme activities of Pleurotus tuberregium (Fries) Singer, cultivated onselected agricultural wastes. Bioresource Technol. https://doi.org/10.1016/j.biortech.2007.08.053

Whiteside, P and Miner, B. (1984). Pye Unicam Atomic Absorption Data Book; Pye Unicam LTD: Cambridge, UK. 